\title{
Exon skipping for DMD
}

\author{
Annemieke Aartsma-Rus ${ }^{1 *}$, Jan JGM Verschuuren², Giles V Campion ${ }^{3}$, Gert-jan B van Ommen ${ }^{1}$, \\ Judith CT van Deutekom ${ }^{3}$ \\ From 6th European Conference on Rare Diseases and Orphan Products \\ Brussels, Belgium. 23-25 May 2012
}

Duchenne muscular dystrophy (DMD) is a severe, progressive muscle-wasting disorder, while Becker muscular dystrophy (BMD) is milder muscle disease [1]. Both are caused by mutations in dystrophin, a protein, which stabilizes muscle fibers during contraction by linking muscle actin to the extracellular matrix. In DMD patients mutations disrupt the open reading frame, generating prematurely truncated, nonfunctional dystrophins [2]. In BMD patients, mutations maintain the reading frame allowing production of internally deleted, partly functional dystrophins.

The exon skipping approach uses antisense oligonucleotides (AONs) to induce skipping of targeted exons during pre-mRNA splicing, with the aim of reading frame restoration, converting of the severe DMD into the milder BMD phenotype [3]. This approach is mutation specific. However, as mutations cluster in a few hotspots, skipping of some exons applies to larger groups of patients (e.g. exon 51 skipping applies to $13 \%$ ) [4].

After promising results in cultured cells and animal models where AON treatment allowed in dystrophin restoration (reviewed in [3]), a first clinical trial was performed by LUMC and Prosensa Therapeutics, where four DMD patients where intramuscularly injected with an exon 51 (GSK2402968/PRO051, a 2'-O-methyl phosphorothioate (2OMePS) AON) [5]. Exon skipping and dystrophin restoration was observed for each patient in muscle biopsies taken 4 weeks after the injection.

Towards systemic application, studies in animal models revealed that dystrophic muscles facilitated uptake of 2OMePS AONs and that subcutaneous delivery was feasible [6]. In a subsequent clinical trial, patients were subcutaneously injected with $2 \mathrm{OMePS}$ AONS targeting exon 51 [7]. Dystrophin was restored in a dose-dependent

\footnotetext{
* Correspondence: a.m.rus@lumc.nl

'Department of Human Genetics, Leiden University Medical Center, Leiden, the Netherlands

Full list of author information is available at the end of the article
}

manner at levels up to $15 \%$. All patients were enrolled in an open label extension study and have received subcutaneous $\mathrm{AON}$ injections at $6 \mathrm{mg} / \mathrm{kg}$ for over 2.5 years. A pivotal, double-blind, placebo-controlled multicenter trial for exon 51 skipping is currently ongoing (coordinated by GlaxoSmithKline).

In parallel, preclinical studies to further optimise treatment regimens are in progress as well as clinical trials for additional exons for exon 44 skipping (PRO044, applicable to $6 \%$ of patients). Trials are planned for exon 45 and 53 skipping (PRO045 and PRO053, both applicable to $8 \%$ of patients).

The mutation specificity of the approach poses challenges to drug development regulations. A concerted effort of academic researchers, industry, regulators and patients is needed to adapt regulations to enable application of these personalised medicine approaches to rare diseases.

\section{Author details}

'Department of Human Genetics, Leiden University Medical Center, Leiden, the Netherlands. ${ }^{2}$ Department of Neurology, Leiden University Medical Center, Leiden, the Netherlands. ${ }^{3}$ Prosensa Therapeutics B.V., Leiden, the Netherlands.

Published: 22 November 2012

\section{References}

1. Emery AE: The muscular dystrophies. Lancet 2002, 359:687-95.

2. Monaco AP, Bertelson CJ, Liechti-Gallati S, Moser H, Kunkel LM: An explanation for the phenotypic differences between patients bearing partial deletions of the DMD locus. Genomics 1988, 2:90-5.

3. Aartsma-Rus A: Antisense-mediated modulation of splicing: Therapeutic implications for duchenne muscular dystrophy. RNA Biol 2010, 7.

4. Aartsma-Rus A, Fokkema I, Verschuuren J, Ginjaar I, van Deutekom J, van Ommen GJ, et al: Theoretic applicability of antisense-mediated exon skipping for Duchenne muscular dystrophy mutations. Hum Mutat 2009, 30:293-299.

5. van Deutekom JC, Janson AA, Ginjaar IB, Frankhuizen WS, Aartsma-Rus A, Bremmer-Bout $M$, et al: Local dystrophin restoration with antisense oligonucleotide PRO051. N Engl J Med 2007, 357:2677-2686.

6. Heemskerk H, de Winter C, van Kuik P, Heuvelmans N, Sabatelli P, Rimessi P, et al: Preclinical PK and PD Studies on 2'-O-Methyl-phosphorothioate RNA Antisense Oligonucleotides in the mdx Mouse Model. Mol Ther 2010.

(c) 2012 Aartsma-Rus et al; licensee BioMed Central Ltd. This is an Open Access article distributed under the terms of the Creative Commons Attribution License (http://creativecommons.org/licenses/by/2.0), which permits unrestricted use, distribution, and reproduction in any medium, provided the original work is properly cited. 
7. Goemans NM, Tulinius M, van den Akker JT, Burm BE, Ekhart PF,

Heuvelmans N, et al: Systemic Administration of PRO051 in Duchenne's Muscular Dystrophy. N Engl J Med 2011, 364:1513-1522.

doi:10.1186/1750-1172-7-S2-A20

Cite this article as: Aartsma-Rus et al: Exon skipping for DMD. Orphanet Journal of Rare Diseases 2012 7(Suppl 2):A20

Submit your next manuscript to BioMed Central and take full advantage of:

- Convenient online submission

- Thorough peer review

- No space constraints or color figure charges

- Immediate publication on acceptance

- Inclusion in PubMed, CAS, Scopus and Google Scholar

- Research which is freely available for redistribution

Submit your manuscript at www.biomedcentral.com/submit 